\title{
Technology Transfer and Diffusion among Manufacturing Small and Medium Enterprises in Indonesia
}

\author{
TULUS TAHI HAMONANGAN TAMBUNAN
}

\begin{abstract}
It is evident everywhere that in manufacturing industry, levels of productivity are higher in large enterprises (LEs), including foreign-owned firms or multinational companies (MNCs), than in small and medium enterprises (SMEs), partly because the former enterprises enjoy higher levels of technological capacity. Thus, for SMES, increased productivity might be facilitated through a scaling-up of knowledge or technology. The case study of the Tegal metalworking industry in Central Java presented in this article shows that the most important channels for the diffusion of knowledge/technology among domestic manufacturing SMEs include subcontracting arrangements with foreign direct investment (FDI). However, the importance of FDI as a source of technology/knowledge varies across the differing types of domestic firms. This study also shows that government agencies are currently the largest providers of training and similar assistance for manufacturing SMEs in the country. Such programmes, however, are rendered less effective by a low level of coverage, a lack of effective evaluation and assessment, and a supply rather than a demand orientation.
\end{abstract}

\section{Introduction}

A key to increased productivity among manufacturing small and medium enterprises (SMEs) is to build their capacities through improved knowledge or technological know-how. This technology development can take place internally (inside the firm) or can be fostered through access to outside sources, such as the transfer of technology from multinational companies (MNCs), technical licensing agreements and imported capital goods.

The main goal of this study is to address the following three research questions. First, what are the main channels used for transferring technology from abroad (mostly from developed countries) to Indonesia? Second, do foreign firms or MNCs play the dominant role in technology transfer to manufacturing SMEs in the country? Third, how effective 
are government programmes in supporting the improvement of technological capacity in manufacturing SMEs?

The structure of this study is as follows. After this introductory first section, Section II compares the productivity of large enterprises (LEs), including foreign-owned enterprises and their technological capacities, with those of SMEs in the manufacturing industry. Section III explores the channels of technology transfer and diffusion. Section IV looks at the effectiveness of government-funded programmes to boost the technological ability of manufacturing SMEs. Section $V$ presents the findings of a case study on knowledge diffusion in the Tegal metalworking industry in Central Java. Section VI offers some concluding remarks.

\section{Productivity in Manufacturing SMEs in Indonesia: An Indicator of Technology Capacity}

A number of researchers have attempted to measure the current technological capacity of Indonesian firms by comparing their levels of labour productivity with that of foreign firms. Recently, Takii and Ramstetter (2005) compared the average levels of labour productivity, as determined by value added/labour ratio, of foreign-owned and domestic medium and large enterprises within the manufacturing sector in Indonesia. ${ }^{1}$ They found that the productivity differentials were often very large in the Indonesian manufacturing sector and varied not only over time but also across industries. If all manufacturing industries are analysed together, Takii and Ramstetter's study shows that compared to enterprises that are fully locally owned, the average level of labour productivity was 388 to 745 percent higher in minority foreign-owned firms; 436 to 594 percent higher in majority foreign-owned firms; and 164 to 542 percent higher in firms with foreign shares of 90 percent or more. Higher levels of labour productivity in local firms than in foreign firms were extremely rare.

These findings support the general assumption that in a developing country such as Indonesia, foreign firms are more productive than local firms because they have relatively large endowments of firm-specific, generally intangible assets. One of the greatest of these intangible assets is assumed to be technological capacity. That minority foreign-owned enterprises appear to be less productive than majority or heavily foreign firms supports the assumption that these enterprises restrict the access of minority-foreign affiliates to these firm-specific assets in order to avoid losing control of them. 
Previously Sjöholm (1999a, 1999b) compared levels of labour productivity of MNCs and domestic firms in Indonesia and came up with results similar to those of Takii and Ramstetter, supporting the thesis that because of their high level of technological and human resources, the level of labour productivity of the MNCs was correspondingly much higher than in the Indonesian firms. Unfortunately, Sjöholm's and Takii and Ramstetter's works are not so useful to us in this study because in their comparisons of labour productivity, they only distinguish between MNC plants and domestic plants in the various manufacturing industries, without differentiating between LEs and SMEs. ${ }^{2}$

Official data from the National Agency for Statistics (BPS) in manufacturing industry supports the theory that the value added/labour ratio increases by size of enterprise. This may suggest that in larger enterprises, the level of technology is higher than that in small ones (see Table 1). BPS splits the size of enterprises into three categories: micro enterprises (MIEs) with one to four workers, small enterprises (SEs) with five to 19 workers, medium enterprises (MEs) with 20 to 99 workers, and large enterprises (LEs) with 100 or more workers. In MIEs and SEs, the labour productivity is much lower than that in MEs and LEs. This finding is not unexpected, since most MIEs and SEs in Indonesia (as in developing countries in general) are traditional enterprises using manual production techniques with a low degree of mechanization. By contrast, LEs (and to a lesser extent MEs) are usually mechanized and computerized, the production processes are much better managed and organized, and they employ more highly skilled workers. In the food and beverages industry, for instance, MIEs and SEs are very simple manufacturing units producing mostly for local markets, in contrast to LEs which are modern production units such as Unilever and Indofood.

Surprisingly, both the 2006 Rural Investment Climate Survey (World Bank 2006) and the Survey on Small Scale and Handicraft Industry in Indonesia from BPS show that the surveyed MIEs and SEs do not regard lack of technological capacity as one of their key constraints. And this

TABLE 1: Value Added/Labour Ratio (Q1; $000 \mathrm{Rp})$ and Manufacturing Total Output Contribution (Q2; \%) by Size of Enterprise in Indonesia, 19992003

\begin{tabular}{|l|r|r|r|r|r|r|r|r|r|r|}
\hline \multirow{2}{*}{ Size group } & \multicolumn{2}{|c|}{$\mathbf{1 9 9 9}$} & \multicolumn{2}{|c|}{$\mathbf{2 0 0 0}$} & \multicolumn{2}{|c|}{$\mathbf{2 0 0 1}$} & \multicolumn{2}{|c|}{$\mathbf{2 0 0 2}$} & \multicolumn{2}{|c|}{$\mathbf{2 0 0 3}$} \\
\cline { 2 - 10 } & $\mathrm{Q} 1$ & $\mathrm{Q} 2$ & $\mathrm{Q} 1$ & $\mathrm{Q} 2$ & $\mathrm{Q} 1$ & $\mathrm{Q} 2$ & $\mathrm{Q} 1$ & $\mathrm{Q} 2$ & $\mathrm{Q} 1$ & $\mathrm{Q} 2$ \\
\hline MEs \& LEs combined & 115.28 & 90.52 & 143.99 & 91.65 & 167.70 & 91.50 & 166.31 & 89.94 & 196. & 90.68 \\
\hline MIEs \& SEs combined & 8.35 & 9.48 & 9.11 & 8.35 & 10.98 & 8.50 & 12.36 & 10.06 & 13.55 & 9.32 \\
\hline
\end{tabular}


despite the fact that other evidence suggests that in some industries, MIEs are able to improve their technology capabilities and that this benefits their performance. For instance, from their studies on SME clusters in Central Java, Sandee $(1994,1995,1996)$ and Sandee et al. $(1994,2000$, 2002) show that these smallest and most traditional enterprises are in a position to adopt innovations in products and production process, even without support from the government. For them, technological capability is a major determinant of business performance. This evidence suggests that there are substantial benefits to be derived from improving technological capabilities.

\section{Channels of Technology Transfer and Diffusion}

\section{The International Transfer of Technology/Knowledge}

There are various channels through which technology may be transferred internationally. These include: foreign direct investment (FDI); technical licensing agreements between foreign and local firms; imports of intermediate and capital goods; education and training in technologically advanced countries; turnkey plants and project contracts; technical consultancies by foreign companies/consultancy firms; and simply through participation in world trade (export). This study focuses on three of these, which are considered as the most important channels of foreign technology transfers to Indonesian firms, including SMEs: (i) FDI, (ii) imports of intermediate and capital goods, and (iii) participation in world trade (Thee 2005).

\section{Foreign Direct Investment (FDI)}

Because of the resources it brings and the attributes embedded in it, FDI can bolster technology capabilities in local industries through the transfer of technology and spillover effects. For example, Thee and Pangestu (1994) assess the technological capability of Indonesian textile, garment and electronics industries to show that in an effort to increase technological capability, Indonesian textile and garment manufacturers established strategic alliances with their Japanese counterparts to open up a vital channel of technology transfer. Similarly, business linkages with foreign firms have been a very important technology transfer channel for electronics firms, especially for consumer electronics and electronic components. 
However, the evidence suggests that the nature and extent of technology that is transferred can be rather limited. For instance, according to their study, technology transfer in the textile industry was limited to improvements in production capability. Whilst important, more sophisticated activities that might help local firms upgrade their technological capabilities, including activities related to pre-investment, project implementation and technical changes in production or product were conducted by Japanese counterparts.

The Global Competitiveness Report 2005-2006 from the World Economic Forum (WEF) also provides evidence to suggest that FDI can be a limited channel of technology transfer from foreign countries to Indonesian firms. Based on a survey of 150 enterprises from all sizes in all sectors (except agriculture) in Indonesia, this report shows that Indonesia ranks 82nd of a total of 103 countries covered in the survey (WEF 2005).

In general, empirical studies on FDI as a channel for technology transfer in Indonesia fail to provide strong evidence to support the general view that there is a significant degree of technology transfer and spillover effect from MNCs to Indonesian firms. ${ }^{3}$ Moreover, whether technology transfer will have a positive effect on the recipient firms or countries depends largely on the absorptive capacity of the firms/host countries; that is, on their ability to understand, assimilate and make effective use of the transferred knowledge or technology.

\section{Imports of Intermediate and Capital Goods}

Intermediate and capital goods embody the technological know-how involved in their production. As a result, trade in these goods in itself promotes the transfer of technology between trading partners. This appears to have been an important channel for technology transfer to Indonesia, as the country has become more heavily dependent on imports of intermediate and capital goods.

The only study available that directly addresses the role of such imports in Indonesia is from Jacob and Meister (2005). They show that such imports have indeed made a significant contribution to the performance of Indonesian manufacturing, especially after liberalization and reforms conducted between 1988 and 1996. Their study is based on an assessment of the contribution of foreign technologies to manufacturing performance in Indonesia at the subsectoral level, in which they combined Indonesian data sets on production and input/output transactions with the $R \& D$, export-to-Indonesia and output data of ten major OECD countries that trade with Indonesia. 
Other studies provide indirect evidence of the importance of imports of capital and intermediate goods. For example, Thee (2003) stresses the role of imports, particularly given the fact that capital goods industries in Indonesia are still underdeveloped. Similarly, BPS data show an increasing share of imported intermediate inputs and capital goods in Indonesia's total imports, suggesting that imports of these goods have been playing an important role in transferring technology from abroad to Indonesian firms.

\section{Participation in World Trade}

Participation in world trade through export has been used effectively by local firms as an important informal channel for the transfer of technologies. For example, local electronics firms in the East Asian countries such as South Korea and Taiwan were able to build up production capabilities through the simple assembly of mature products for exports, often developed through technical assistance provided by foreign buyers. ${ }^{4}$ This process of coupling exports with technology development is called 'export-led technology development' (Hobday 1994: 335).

Similarly, since the mid-1970s, export has been an important informal channel for the transfer of technology from abroad to Indonesian firms, including SMEs. For example, the remarkable export performance of the garment industry in Bali and that of the furniture industry in Jepara (Central Java) since the mid-1970s share important characteristics with the experience of these East Asian firms. The case of Bali's garment industry in paticular shows the importance of foreign buyers (i.e. foreign firms, businessmen and tourists) as a vital source of innovation in their role as marketing intermediaries, connecting local producers with retail outlets abroad. In the process, these intermediaries dispensed important information on design and production techniques. Foreign buyers provided information and technical and managerial assistance on plant layout, the purchase of the most appropriate machines, and quality control methods, and also often acted as technical consultants to SMEs. As a result, these firms were able to achieve higher levels of efficiency and accuracy (Cole 1998).

Foreign buyers also provided vital information as well as technical, managerial and marketing assistance during the development of the export-oriented furniture industry in Jepara, Central Java. As a result, the quality of Jepara furniture has been steadily upgraded (Sandee $e t$ al. 2000: 5-7). Foreign buyers have also played a crucial role in providing guidance to SMEs on the furniture designs popular in the export 
markets and the quality standards required to penetrate these markets (Berry and Levy, 1994; Schiller and Martin-Schiller 1997).

These two cases show that SMEs in the two regions have benefited from the inflow of technologies through their participation in foreign trade, suggesting that the more open the regional economy, the greater their chances of upgrading skills and technologies through this means. However, an important conclusion from these studies is that local SMEs must have some basic industrial competence in their particular field of activity to be able to absorb the inflows of technology or knowledge. In this regard, Bali and Jepara are still exceptional cases. In general, the capability of Indonesian manufacturing SMEs, especially MIEs and SEs in rural areas, to adopt and deploy new technologies is limited due to the lack of management capacity, access to information, skilled workers and capital.

\section{Domestic Diffusion of Technology/Knowledge}

Although the international transfer of technologies is essential, such transfers tend primarily to impact larger and predominantly urbanbased enterprises in the country. For such technological knowledge to improve the productivity of rural manufacturing SMEs throughout the country, effective mechanisms are needed for the domestic diffusion of technical knowledge from the first local recipient firms to other local firms, or from a local university as the first recipient to local firms. ${ }^{5}$

Domestic diffusion of the transferred or imported technology or knowledge can occur in various ways ${ }^{6}$ and the most immediate and direct channel is through subcontracting, where buyers assist SME suppliers to meet technical standards for inputs. In addition, there is a growing recognition of the importance of long-term networks as a means of achieving the diffusion of technology/knowledge. Through networks an entrepreneur can obtain knowledge from other entrepreneurs in the same sector or from universities, R\&D institutions or NGOs. The literature on networks in turn explores two main issues: strategic alliances and clusters.

\section{Subcontracting}

During the Soeharto era (1966-98), the government imposed a system of protection and local content rules in a number of industries, including machinery, electronics and the automotive industry, as part of its import substitution policy. In these local content rules all assembling 
industries should use some components produced locally. These rules stand as a clear lesson in how government interference does not facilitate the use of subcontracting as a means for achieving the domestic diffusion of technology or knowledge. The main aim of this policy was to encourage industrialization in the country and also to encourage a pattern of industrial development that followed the ind ustrial pyramid model from Japanese. In this model, MIEs are at the base to support SEs, which then support MEs and the latter support LEs at the top of the pyramid (TAF 2000).

However, industrial development in Indonesia did not follow the same pattern as in Japan. On the contrary, the local content policy resulted in a vertically integrated production system within LEs. The Asia Foundation (TAF 2000) argues that the lack of success of this policy in creating strong interdependence between SMEs and LEs was largely due to the government's excessive interference, aimed at replacing market mechanisms.

The economic rationale behind this local content policy was to create a captive market for domestic products in order to increase the economic scale of production and thereby to increase efficiency. However, government interference went too far. The government decided which products were to get priority in this policy, and introduced fiscal incentives in line with the type of priority recipient products. The determination of priorities did not appear to have been based on economic considerations, such as SMEs' capacity for investment and absorption of technology.

Similarly, Thee $(1990 b, 1997)$ argues that such production linkages did not develop smoothly during the New Order era because of market distortions and the lack of skills and low technological capabilities of local firms, especially SMEs. SRI International (1992) found that production linkages between LEs and SME clusters were weak and only a small number of clusters (all located in Java) established subcontracting relationships with LEs. The general impression from other studies is also that subcontracting between LEs and SMEs is weak, mainly because the latter cannot meet the required quality standards, due to their lack of technology and skills. ${ }^{7}$

Although during the New Order era the local content rules as mentioned above were largely unsuccessful in developing viable domestic supplier firms, successful private-led subcontracting networks did arise in some industries and these did facilitate technological capacity building. One example is the case of Astra Otoparts, part of the Astra International business group, Indonesia's largest integrated automo- 
tive company. Through Astra Otoparts, Astra International was able to develop several SMEs into efficient and viable suppliers. As a result of the rigorous training which Astra provided to local suppliers with potential, over time these suppliers were able to produce a wide range of parts and components for cars and motorcycles according to the high quality standards set by Astra, and also to meet its strict delivery schedules.

\section{Strategic Alliances}

Strategic alliances are defined as the development of a long-term and stable relationship with other enterprises. ${ }^{8}$ Many researchers such as Perry and Pyatt (1995) and Weaver and Dickson (1995) maintain that such alliances form a key component of successful firms' competitiveness. Such partnerships are especially important for SMEs, which in general have limited capital, human resources, information and technology. Through collaborations, LEs can share their capacities with SMEs in order to reduce costs, without having to reduce the creativeness and competitiveness of each company involved (Weaver and Dickson 1995).

Strategic alliances are quite common among MEs. Tambunan (2006: 237) surveyed 124 respondents, most of which were MEs, and found that more than 50 percent of them had strategic alliances with other firms. However, the percentage of those with strategic alliances differs among various industries. A majority of the firms surveyed in food, beverages and tobacco industries and industries manufacturing metal products, machines, tools and other capital goods had some kind of strategic alliances with other firms, while the proportion in other industries was considerably lower.

Most of the firms surveyed have had more than one type of strategic alliance (see Table 2). The most important types are long-term marketing output agreements, purchase-supplier alliances (i.e. cooperation between input suppliers and their purchasers), joint ventures with other enterprises, and cooperation in technology. With respect to the kinds of assistance that the surveyed firms have received from their strategic alliance partners, technology, market information and skills training are the most important. Cooperation in marketing, rather than in technology, is also the most prevalent form of partnership in a study of 300 enterprises in the food, timber products and clothing industries in six provinces in Indonesia (TAF 2000). 


\section{Table 2:}

Types of Strategic Alliances by Surveyed Firms in Indonesia, 1997

\begin{tabular}{|l|c|}
\hline Types & Percentage Use \\
\hline Long-term marketing agreements & $25.3 \%$ \\
\hline Purchaser-supplier alliance & $23.9 \%$ \\
\hline Joint ventures with other SMEs & $22.8 \%$ \\
\hline Technology alliances & $22.0 \%$ \\
\hline Outside contracting & $21.2 \%$ \\
\hline Licensing & $20.0 \%$ \\
\hline Joint ventures with LEs & $18.9 \%$ \\
\hline Equity investments & $14.8 \%$ \\
\hline Export management & $13.4 \%$ \\
\hline
\end{tabular}

Source: Tambunan (2006) (field survey 1997)

\section{Clusters}

Clusters can be defined as geographical concentrations of industries that gain performance advantages through co-location (Doeringer and Terkla 1995) and they can be a powerful means for SMEs to overcome constraints on their development. Through cooperation in a cluster, SMEs may take advantage of external economies such as the presence of suppliers of raw materials, components, or new technologies embodied in new machinery and parts; the presence of workers with sector-specific skills; and the presence of workshops that make or service the machinery and production tools (Humphrey and Schmitz, 1995). Moreover, with the clustering of enterprises, it becomes easier for the government, LEs, universities/research institutes and other agencies to provide supporting services. These might include technical development and management training as well as general facilities such as large machinery for raw material processing. Such services and facilities would be very costly to provide if provided to individual enterprises in dispersed locations (Tambunan 2000).

While clustering is commonplace throughout the developing world, well-developed networks among enterprises inside clusters and between the clusters and external agencies are rare. Highly developed inter-firm divisions of labour, subcontracting and cases where technical information flows have resulted in ongoing technical innovation tend only to be observed in the more advanced clusters of South East Asia and Latin America (Nadvi and Schmitz 1994). However, internal networks among 
firms within clusters, as well as external networks, are important for the development of technology inside the clusters. ${ }^{9}$

Unfortunately, Indonesia's clusters appear to be quite weak in this regard. For example, Sato (2000) saw little evidence of positive effects of clustering, as she found no inter-firm specialization of work processes and no joint actions in marketing, production, distribution or technological development among the firms studied. Supratikno $(2001,2002)$ also found that, in general, very limited inter-firm specialization and cooperation among producers inside the clusters. He concluded that the importance of a cluster for production development, including technology and marketing, depends on whether there are leading/ pioneering firms inside the cluster. These are usually larger and faster growing firms that are able to manage a large and differentiated set of relationships with firms and institutions both within and outside clusters. Furthermore such firms have generally utilized cutting-edge technologies in production. He cited as examples the clove cigarette cluster in Kudus, the tea-processing cluster in Slawi, and tourism clusters in Bali. In the case of the clove cigarette cluster in Kudus, their products are able to outperform products from Philip Morris and BAT. Similarly, the teaprocessing cluster in Slawi, led by the large company Sostro, has grown to become the market leader in the Indonesian soft drink market, leaving giant Coca-Cola behind.

By contrast, Sandee et al. (2002) emphasize the role of traders, suppliers of raw materials and other inputs, and other market agents in introducing new technologies into clusters. Weijland's studies (1992) emphasize the importance of middlemen or traders as a source of knowledge transfer to the clusters.

\section{The Effectiveness of Government and Government Funded Programs to Build Technological Capacity of Manufacturing SMEs}

In Indonesia, almost all known types of government intervention to promote the development of SMEs have been tried at one time or another. These include subsidized credit, such as credit for small farmers and village cooperatives (KUD), small-scale credit (KIK, KMKP, KUK), and credit for village units (KUPEDES); the development of small rural development banks (BKD); human resources development training such as production techniques, general management (MS/MUK), management quality systems ISO-9000, and entrepreneurship (CEFE, AMT); 
providing total quality control advice, technology and especially internet access (WARSI) and advisory extension workers; subsidized inputs; facilitation, the setting up of Cooperatives of Small-Scale Industries (KOPINKRA) in clusters; the development of infrastructure, building special small-scale industrial estates (LIK), partnership programmes (the 'Foster Parent' scheme), and small business consultancy clinics (KKB); the establishment of the Export Support Board of Indonesia (DPE); the establishment of common service facilities (UPT) in clusters; and the implementation of an incubator system for promoting the development of new entrepreneurs. All these have been initiated by the central government and implemented through local government offices.

The SMERU Research Institute has mapped out most of the important assistance programmes to strengthen MIEs and SEs provided by central government and non-government institutes, showing that most are run by the central government (SMERU 2004). The data in Table 3 reveal that there are 64 institutions with such programmes and 594 identified programmes, two-thirds of which are provided by the central government. ${ }^{10}$ Other programmes are conducted by NGOs (18\%), donor agencies $(8 \%)$, banking institutions $(5 \%)$, private companies, mainly LEs $(2 \%)$, and other institutions. The government is still running 127 different support programmes.

Table 3: Number of Institutions and Assistance Programmes to Strengthen MIEs and SEs, 1997-2003

\begin{tabular}{|l|c|c|c|c|}
\hline \multirow{2}{*}{ Institutions } & Number of & \multicolumn{4}{|c|}{ Number of assistance programmes } \\
\cline { 3 - 5 } & institutions & Total & Still running total & $\%$ \\
\hline Government institutuions & 13 & 388 & 127 & 32.7 \\
\hline Banking institutions & 7 & 31 & 25 & 80.7 \\
\hline Private companies & 10 & 12 & 12 & 100.0 \\
\hline Donor agencies & 8 & 46 & 15 & 32.6 \\
\hline NGOs & 20 & 109 & 79 & 72.5 \\
\hline Others & 6 & 8 & 8 & 100.0 \\
\hline Total & 64 & 594 & 266 & 44.8 \\
\hline
\end{tabular}

Source: SMERU (2004).

Table 4 shows the type of assistance provided by these programmes. The number of activities within each programme also varied, but generally ranged between one and three. In total, the most common types of activities are the provision of training (22.9\%), capital assistance/credit $(17.3 \%)$, facilitation $(16.1 \%)$, and the dissemination/introduction of new technology $(15.2 \%)$. 


\begin{tabular}{|c|c|c|c|c|c|c|c|c|c|c|}
\hline$\stackrel{\mathscr{f}}{\underline{\Xi}}$ & ت્ & $\stackrel{?}{\sim}$ & ๙ิ & $\begin{array}{l}\vec{\sigma} \\
6 \\
-1\end{array}$ & $\begin{array}{l}\stackrel{0}{\sim} \\
\text { (n) }\end{array}$ & $\widehat{\alpha}$ & 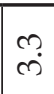 & $\begin{array}{l}\stackrel{N}{n} \\
\stackrel{1}{n}\end{array}$ & $\stackrel{+}{\sim}$ & ำ \\
\hline$\frac{0}{3}$ & 苞 & $\begin{array}{l}0 \\
\stackrel{0}{N}\end{array}$ & 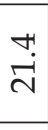 & $\stackrel{0}{0}$ & 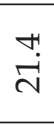 & $\stackrel{\circ}{\circ}$ & $\stackrel{-}{\wedge}$ & $\stackrel{0}{0}$ & $\stackrel{\circ}{\circ}$ & ț. \\
\hline $\begin{array}{l}\text { D } \\
\text { D } \\
\text { N }\end{array}$ & $\begin{array}{l}\infty \\
0 \\
Z\end{array}$ & $\begin{array}{l}0 \\
\grave{2}\end{array}$ & §่̊ & $\begin{array}{c}\widetilde{N} \\
\infty \\
\sim\end{array}$ & & هُ & - & חִ & $\widehat{O}$ & $\stackrel{N}{N}$ \\
\hline 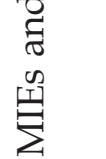 & 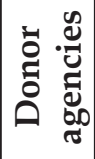 & $\begin{array}{l}0 \\
\dot{\sim}\end{array}$ & $\stackrel{\circ}{\circ}$ & $\stackrel{0}{\Lambda}$ & $\begin{array}{l}\infty \\
\infty\end{array}$ & $\begin{array}{l}0 \\
\infty\end{array}$ & $\sigma_{0}^{\circ}$ & $\widetilde{\sigma}$ & $\stackrel{\circ}{\circ}$ & ָ̊. \\
\hline 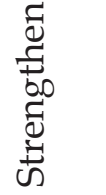 & 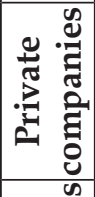 & $\begin{array}{c}0 \\
\stackrel{0}{2} \\
\end{array}$ & ָี & $\begin{array}{l}+ \\
\sigma \\
\sim\end{array}$ & $\stackrel{\infty}{\sim}$ & $\begin{array}{l}0 \\
1 \\
1\end{array}$ & $\begin{array}{l}\stackrel{\vartheta}{n} \\
\ddot{1}\end{array}$ & $\stackrel{\circ}{\circ}$ & $\stackrel{\circ}{\circ}$ & تُ \\
\hline 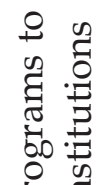 & صـ & aิ & $\stackrel{\curvearrowright}{\oplus}$ & $\begin{array}{l}\infty \\
\sigma\end{array}$ & $\stackrel{\infty}{\Lambda}$ & $\stackrel{\circ}{\mathrm{i}}$ & $\ddot{m}$ & $\stackrel{\circ}{\circ}$ & $\stackrel{\circ}{0}$ & $\sigma^{\infty}$ \\
\hline 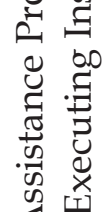 & 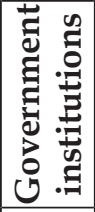 & $\begin{array}{l}m \\
n \\
0\end{array}$ & 곡 & 号 & $\stackrel{-}{\sim}$ & ִָ & $\begin{array}{l}0 \\
\text { ले }\end{array}$ & ণิ & $\stackrel{n}{+}$ & ○. \\
\hline 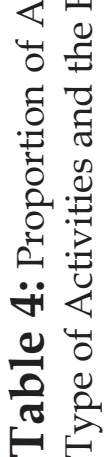 & & 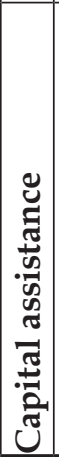 & . & 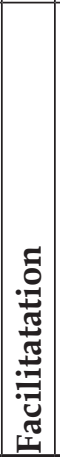 & 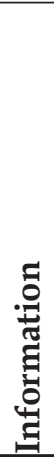 & : & 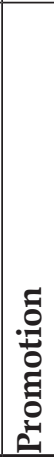 & 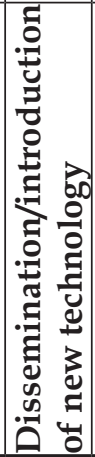 & 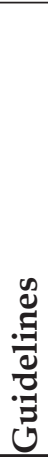 & 选 \\
\hline
\end{tabular}


The table shows that government agencies most often introduce new technology $(27.9 \%)$ and provide training $(21.1 \%)$, whereas other institutions mostly provide capital assistance. Of all the executing institutions, government agencies play the most prominent role (50.9\%), followed by NGOs (29.4\%) and donor agencies (10.1\%). Based on the type of activity, training is mostly undertaken by government institutions (46.9\%) and NGOs (37.2\%). Capital assistance is mostly provided by local and international NGOs (50.3\%), followed by government institutions (15.5\%) and banking institutions (14.9\%). Facilitation is mainly provided by NGOs (52.4\%) and government institutions (35.7\%).

Despite their large number, the level of coverage of assistance programmes is very low. The Integrated Business Survey (SUSI) 2003 from BPS shows that out of a total 481,714 units of non-farm MIEs and SEs that received government support in 2003, some 203,563 firms (or $43 \%$ of the total) received support through one or more of the various government programmes. The remainder ( $57 \%$ of the total) received support from such agencies as NGOs and foreign foundations. Also, the coverage is

FIGURE 1: Distribution of Total Non-farm MIEs and SEs Receiving Support from the Government in Indonesia by Region, 2003 (\%

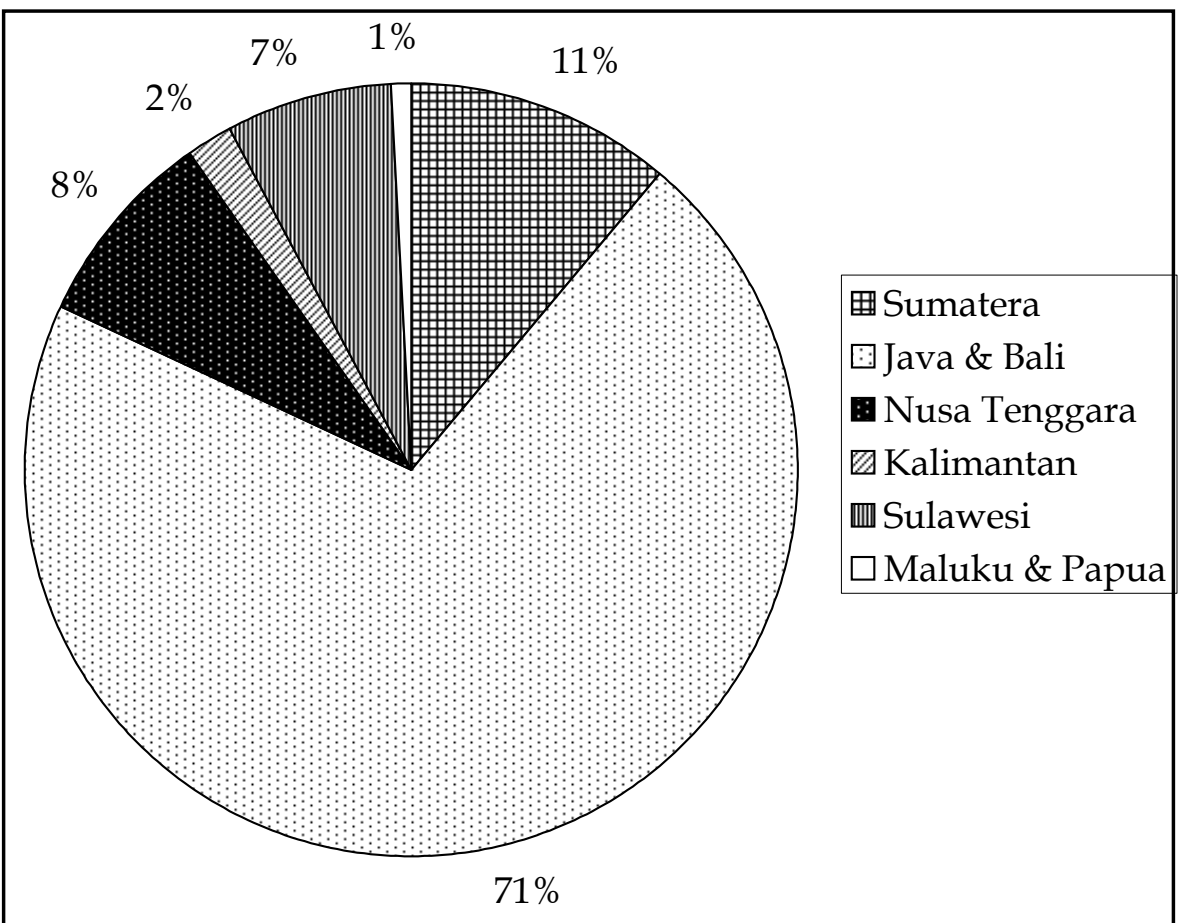

Source: BPS (SUSI 2003). 
heavily skewed towards Java and Bali, i.e. $71 \%$ of the total recipient non-farm MIEs and SEs are found in Java and Bali (Figure 1).

This is not only because the majority of these enterprises are located in those regions, but it is much easier to conduct a central governmentinitiated programme in inner than in outer Indonesia due to better infrastructure facilities (e.g. roads and telecommunication links) and the availability of supporting agencies such as banks, trading houses and business associations. Thus, uneven economic development between

FIGURE 2: Percentage of Non-farm SEs and MIEs Receiving Government Assistance (as a \% of Total Non-farm SEs and MIEs in Each Region) 2003

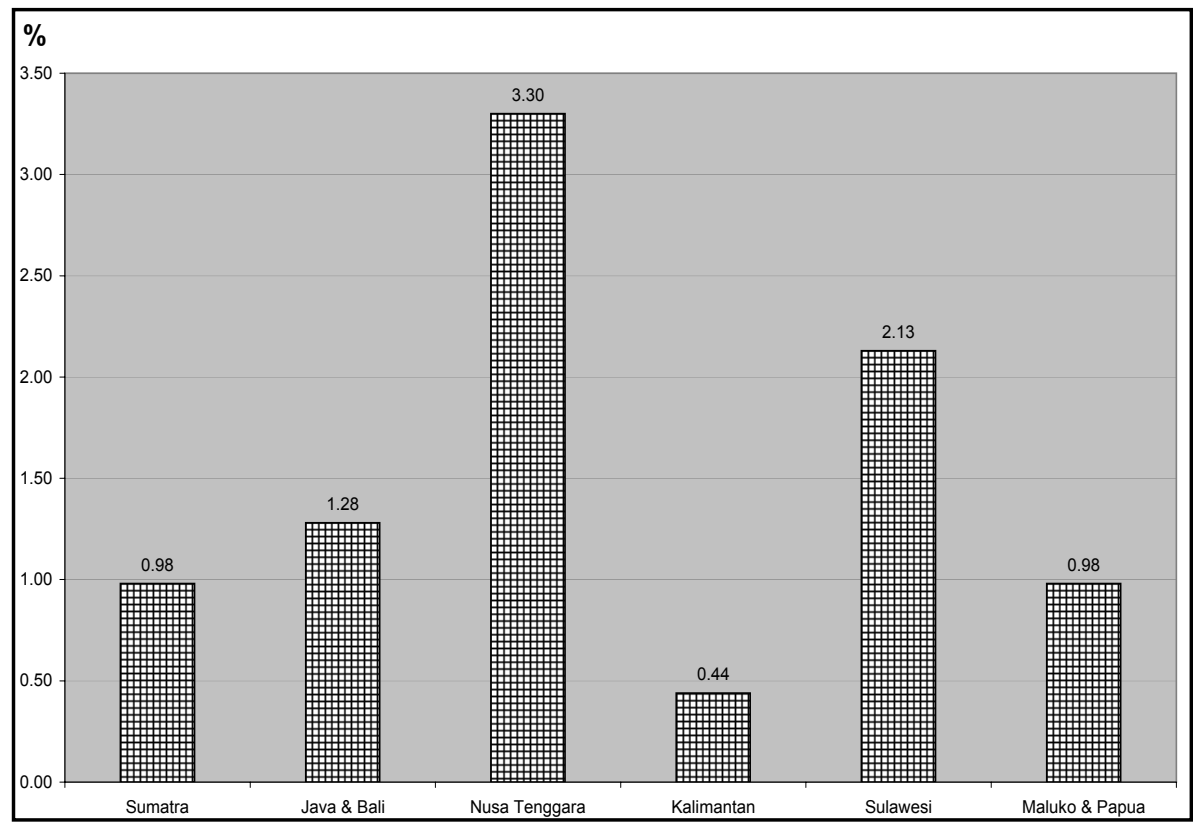

Source: BPS (SUSI 2003).

inner and outer regions also plays an important role in affecting this distribution. Moreover, in Java SMEs are mostly located in clusters close to urban areas, while in outer regions they are scattered individually far from cities, which makes it more difficult for local government staff to recruit potential participants in a programme.

However, as a percentage of total non-farm MIEs and SEs in the region, Nusa Tenggara (both West and East) scores the highest, while Java (including Bali) ranks third (Figure 2). This variation depends on many factors, including the willingness of owners/entrepreneurs to attend a government-sponsored programme, the availability of alternative pro- 
grammes from non-government institutes, and the proactivity of local government staff to encourage local entrepreneurs to participate.

Despite this low level of coverage, those enterprises that do receive assistance appear to benefit from it. To assess the effectiveness of assistance programmes, SMERU (2004) studied 172 MIEs and SEs in six Kabupaten/Kota in Java. These firms are mostly informal, non-legal entities whose turnover and employees fluctuate over time, and which operate with minimal or no technology. A large number of MIEs (58.6\%) and SEs $(63 \%)$ stated that the assistance they had received had increased their revenues. Some MIE owners stated that, as a result, they had been able to develop their businesses further. Unfortunately, it is not established whether there was an increase in knowledge or technological capability as a result of the training or technical assistance received.

Typically, government programmes are evaluated according to the number of enterprises that participate. The actual outcomes of the programme are generally not assessed. Thus, it is impossible to ascertain for most government programmes whether they have proved effective in improving technical ability. Moreover, programme benefits need to be compared with programme costs to determine the net benefits, but this is generally not done (van Diermen, 2004).

A few studies suggest that most SME development programmes have not been very successful. ${ }^{11}$ For instance, the Foster Parent (FP) programme attempts to create productive linkages between large and small firms, but levels of participation are low and very little training and technical assistance are supplied. ${ }^{12}$ Furthermore, the emphasis is on the provision of capital and marketing assistance. SUSI data 2003 (BPS) show that only 11 percent of MIEs and 3 percent of SEs in Indonesia have received training and technical assistance from this programme. The general impression is that the FP is essentially a non-market mechanism to pressure LEs and SMEs into a 'forced marriage'. International evidence shows that patterns of business linkages or partnerships between firms are not established through mandatory requirements; rather, they are established when they offer commercial benefits to both parties.

Low participation is a common feature of such programmes. For example, SUSI data (BPS) show that the majority of MIEs and SEs in Indonesia are not members of KOPINKRA. The reason for this is mentioned by Klapwijk (1997: 65), who states that:

In view of the wide definition of small industry employed by the Ministry, much of the promotion efforts may have bypassed the smallest enterprises that are most in need of assistance ... The extension officers generally have 
little technical or business experience, and training or other technical facilities have been largely provided according to the directions of central planners, rather than having been adapted to local needs.

Another more comprehensive technical assistance programme has involved the development of technical service units (UPT)) in existing SME clusters of similar industries across provinces. These units provide extension and technical services and training courses, and are staffed by government technical officers who have received special training. Van Diermen (2004: 51) concludes that the UPT extension service programme has achieved poor results. It has failed to deliver efficient services, to target appropriate recipients, or to address the important criteria of providing a net benefit to society and/or effectively addressing equity or fairness objectives. In particular, van Diermen notes the following:

1. Types of services are highly supply oriented rather than demand driven.

2. Most of the machines and equipments are outdated. Originally, these units were supplied with modern technological machines and equipments. However, over the years, especially after the economic crisis of 1997/98, budgetary constraints prevented the replacement of the existing equipment.

3. Services were delivered indiscriminately to clusters.

4. The staff of the UPT did not receive the appropriate training to respond to entrepreneurs' needs.

5. There is not enough flexibility in the system to respond to the changing needs of SMEs, possibly due to the bureaucratic structure of the UPT.

Based on his analysis of the effects of macro- and micro-policy environments on rural industries in Indonesia, van Diermen (2004) comes to the following conclusions: (i) few of the micro-policies (programs) implemented by the government have had a lasting impact on improving rural SMEs; (ii) a significant number of macro- and micro-policies placed additional costs and burdens on rural SMEs' compliance, which has led to most operating outside of the formal economy; and (iii) macropolicies that created a favourable economic environment (as reflected by consistently high GDP growth rates and not biased in favour of LEs) provided the best stimulus for SME growth.

Based on their study on a furniture cluster in Jepara (Central Java), Sandee et al. (2000) conclude that public intervention is likely to have contributed to the success of this cluster. A comprehensive development package - including technical upgrading through the provision of a 
common service facility for wood drying; export training and support for participation in trade fairs; and investment in improvement of the regional infrastructure (container facilities, roads, telephone) - helped the cluster to gradually develop export markets.

On the other hand, Sato's (2000) field study of several clusters in the metalworking and machinery industry in Java concludes that the successful development of these clusters has been achieved without significant government support. Her findings on the effectiveness of government programmes for the development of SMEs is also supported by Tambunan's (1998) findings on rattan industries in Padang (West Sumatra). They both conclude that the government's efforts to support the clusters have not yielded positive results. One reason appears to be the lack of coordination between the various government agencies. In many clusters, local government agencies such as regional offices of the State Ministry for Cooperatives and SMEs, the Ministry of Industry, state universities and skills training centers for workers (Balai Latihan Kerja) from the Department of Manpower provide some support. However, sometimes different agencies provide similar schemes/programmes, and there is little attempt to coordinate their efforts.

While the government is the largest supplier of training programmes (see Table 4), the evidence suggests that the quality and relevance of the training provided have been poor. Most of these programmes do not appear to have been very effective in upgrading the technological capabilities of the firms trained. For example, Sandee (1994: 152) notes that training materials and other information do not always match the needs of the producers:

In practice, direct assistance frequently concerns brief training sessions of one or two days for a selected group of producers. Such sessions are characterized by a great deal of theory and little attention is paid to how to improve the actual running of the business of particular activities.

Universities and research institutes can also contribute to the diffusion of knowledge to domestic firms, particularly manufacturing firms, through publications, patents and consultancy services (Agrawal 2001). In Indonesia, the public science and technology institutes consist of the 12 national-level and several regional-level R\&D centres of the Agency for Industrial Research and Development (BPPI), the Department of Industry, and the research centres of the non-departmental government research institutes, particularly the Indonesian Institutes of Sciences (LIPI) and the Agency for the Assessment and Application of Technology (BPPT). However, BPPI's R\&D centres are mostly engaged in product 
certification, training and testing activities for manufacturing firms, particularly state-owned companies and private SMEs. Their research staffs are generally not well trained and are often unaware of the latest technological developments in their fields. Moreover, much of their laboratory equipment is obsolete because the centres are underfunded, particularly since the economic crisis of 1997/98 (Lall and Rao 1995). Hence, in general they are not able to provide adequate technical information or technology support services to Indonesia's manufacturing firms (Thee 1998).

The non-departmental government institutes, particularly LIPI and BPPT, are better funded, better equipped and better staffed, with highly trained researchers, many of whom have pursued postgraduate training abroad. However, like the Department of Industry's R\&D institutes, the research centres of LIPI and BPPT have not played a significant role in developing the technological capabilities of Indonesia's non-farm firms, particularly in manufacturing industry. The reason for this is that they have generally not been able to establish mutually profitable linkages with national industry, particularly private industry. Because of their lack of contact with national industries, they are generally not aware of the technological needs of private industry and therefore lag behind world technological frontiers (Lall and Rao 1995). As a result of their failure to establish mutually profitable linkages with non-farm firms, most, if not all, of their research is supply rather than demand driven (Thee 1998).

Moreover, the universities and R\&D institutes are located mainly in urban areas, having little interest in the problems of rural firms. The available literature confirms that spillovers from universities or R\&D institutes to firms are positively correlated with geographical proximity (see e.g. Anselin et al. 1997).

The government-initiated programmes discussed above were initiated and sponsored by the central government in the pre-economic decentralization and regional autonomy era prior to 2001. Nowadays, many central governmental economic developmental initiatives have been transferred to the provinces and, in particular, to the regencies within the provinces. This also includes development programmes for SMEs, in which local governments must themselves initiate and finance programmes to support SMEs in their own regions. Unfortunately, no studies have been conducted to date to examine the effect of these economic and power transitions from central to regional government on SME development programmes. However, a number of official re- 
ports from the State Ministry for Cooperativse and SMEs reveals that some central government programmes have ceased to operate, while local governments have been slow to launch new programmes. Lack of funding is often cited as the main reason, although lack of initiative may well be the primary cause as local governments are accustomed to receiving orders from the central government (a typical 'top-down' development approach during the pre-economic decentralization and regional autonomy era).

\section{Evidence of Knowledge Diffusion in the Tegal Metalworking Industry}

Tegal district is located near the north coast of Central Java on key trucking and rail routes. Major industries in the area include food processing, textiles and furniture. The district generates 22.09 percent of its annual income from the industrial sector, compared to 24.24 percent from trade and 24.62 percent from the agriculture sector. These three sectors are the largest contributors to the district economy (Bappeda, 2005, and BPS, 2005).

Tegal district is one of the few areas in Indonesia to have a metalworking cluster. The Tegal metalworking industry employs about 30,029 workers out of a total of 118,820 (around 25 percent) workers constituting the district's industrial sector. There are around 2,811 metal workshops in the district. Among these there are seven sentra, or groups of geographic agglomerations of metal enterprises producing the same metal products, such as components or spare parts for ships and vehicles. Since the New Order era, sentra have become the focus of government development strategies for SMEs in all manufacturing subsectors, including the metalworking industry in Tegal district. The majority of metal workshops are small, employing less than 20 workers, mostly male.

Most of Tegal's metal workshops rely on the same basic metalworking technologies, e.g. casting, cutting, bending, drilling or stamping (depending on product), machining, welding, finishing (painting or electronic plating depending on product), and assembly. Their comparative advantage has been in fulfilling small orders for simple metal products or components. The small size of the workshops gives them greater flexibility and Tegal's abundant cheap labor can outweigh the productivity advantages of more capital-intensive production. There is often intense price competition among workshops.

Tegal district has been a metalworking centre since the mid-1800s 
when it was the locus of several sugar-processing factories and related enterprises, including locomotive repair shops and metal processing factories. The industry continued, thriving particularly under the New Order's massive infrastructure and development agenda. At the beginning of the 1980s, the first subcontracting activity started in the district, sparking government activity to develop the metalworking industry.

\section{Types of Workshops}

The structure of the Tegal metalwork value chain is illustrated in Figure 3. According to the size of production and the level of production sophistication, there are two types of workshops in the Tegal metalworking industry: (i) MEs and LEs called inti and (ii) SEs and MIEs called plasma. Inti workshops receive orders for metal components from large private companies (LEs) outside the district. Large inti workshops employing a total of up to 100 men derive a majority of their income from subcontracting work. During the survey in 2005, there were several large private companies that subcontracted work to Tegal metal workshops, including PT Komatsu Indonesia Tbk, PT Daihatsu, and some divisions of the Astra Group such as PT Sanwa and PT Katshusiro. These companies often source metal components from several parts of the country, mostly in West Java. Among these companies, the most prominent is PT Komatsu Indonesia Tbk, which is a subsidiary of a Japanese company that established subcontracting production linkages with Tegal metal workshops in 1998. This company produces various types of equipment for construction and mining activities under the global trademark of Komatsu, such as hydraulic excavators, bulldozers, motor graders, frames and related components, cast steel products as well as dump tracks.

Plasma workshops usually hire cheap, unskilled labour or use family members as unpaid workers (helpers). The owner normally passes basic metalworking skills on to his employees, leaving the technical capacity of the workshop highly dependent on the technical capacity of the owner. Inti workshops often subcontract part of their production to plasma workshops.

Inti and plasma workshops that have no subcontracting businesses with inti workshops manufacture entirely for the wholesalers and retailers or sell their products directly to local consumers rather than through these marketing channels. Many wholesalers and retailers purchase goods from Tegal metal workshops for resale in urban stores. 
FIGURE 3: Structure of the Tegal Metalwork Value Chain

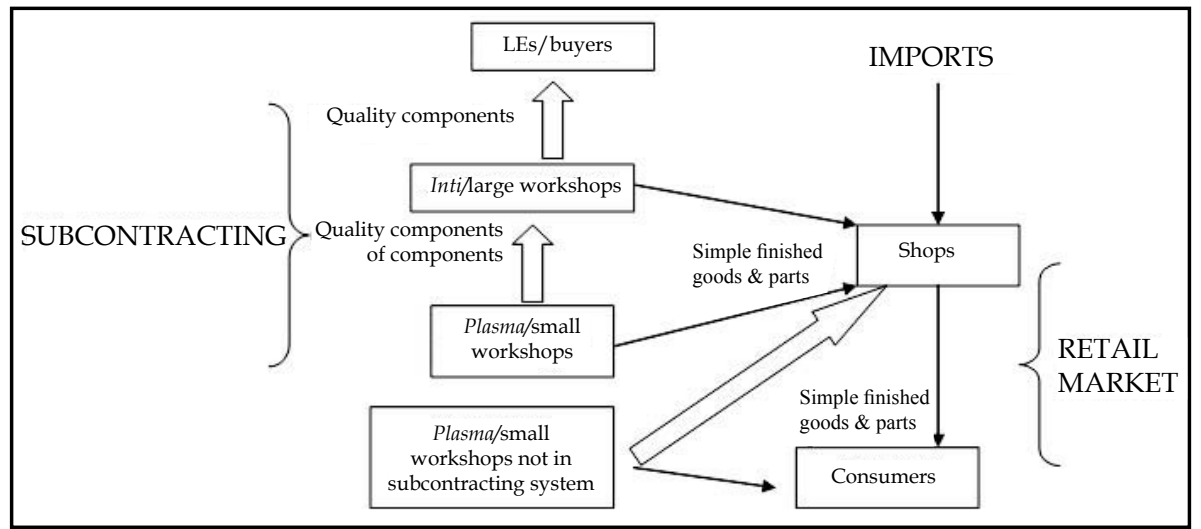

\section{Methodology}

This case study is based on two weeks of fieldwork in Tegal district. In-depth interviews were carried out with 34 respondents: one representative of PT Komatsu, five inti workshops (including three of the four inti workshops directly meeting subcontracting orders for PT Komatsu), three plasma, nine owners of retail manufacturing metalworking firms, two retailers, four NGOs and ten government representatives. These respondents were selected from four subdistrits, i.e. Adiwerna, Talang, Desa Kebasen and Desa Dampyak. The research sampling focused on clustered metal workshops in the automotive and shipbuilding industries. ${ }^{13}$ During the fieldwork, two focus group discussions (FGDs) were held in Desa Kebasen, in which the workshop owners themselves participated. Discussions focused on the needs of their businesses, and assessment of government and private sector training that they had received over the last five years.

\section{Findings}

\section{The Major Knowledge Providers}

Tegal District's main external knowledge providers are LEs, just as PT Komatsu provide to their subcontractors (i.e. inti workshops), and to a lesser extent local government. Some domestic retail market suppliers also act as knowledge providers by informing metal workshops about consumer preferences, market demand and new innovations.

To access knowledge from LEs, however, a workshop must have at- 
tained a certain level of technical and managerial expertise. Larger metal workshops are more likely to adopt new technologies in their bid to become subcontracting inti to LEs. By building upon existing technical and managerial capacity, larger workshops are able to enter a virtuous circle where quality output leads to subcontracts which lead to private training provided by LEs.

Training provided by LEs has proved to be the most successful method of efficiently transferring knowledge to selected inti workshops. While government-led initiatives attempt to cover a broader range of workshops covering more topics, this has not resulted in the efficient transfer of high-quality, usable knowledge. Though a good reputation and personal connections are important, LEs require proof that a workshop has the capacity to produce high-quality components. An audit is held to determine whether the workshop has the required machinery, manpower, facilities, legal standing and competency in ISO standards. The potential subcontractor is then requested to produce a sample component by providing technical drawings. Before an agreement is signed, LEs will often ask for a trial run of the mass production process, subjecting the output to quality control tests.

After winning a contract, an inti subcontractor has access to a significant level of technical training. According to a subcontractor of PT Komatsu, training is directly addressed to the technical needs of the workshop to meet the production requirements of Komatsu. Indonesian experts from the Jakarta Komatsu office who were heading up the training sessions clearly delivered the necessary knowledge and emphasized practical applications, with 90 percent of the training time spent in hands-on experience. Trainers also help the workshop to identify and troubleshoot potential problems.

This style of knowledge diffusion has two important limitations. First, it focuses training only on larger inti workshops, with smaller subcontracting firms (plasma) benefiting only indirectly or, in the case of small retail market firms, deriving no benefit at all. Second, LE training does not seek to develop the inti workshops' capability to outperform their capacity as low-cost production centres for selected components. Moreover, LEs do help inti workshops to build capacity to manufacture component parts, but there has been little interest in upgrading from specialized parts manufacture to manufacture and assemblage of finished products.

Most plasma workshops lack the technical ability to produce complicated components with the precision required by LEs, thus making it 
unlikely that they will receive subcontracting orders. Plasma workshops often use second-hand or homemade equipment. They hire low-skilled, low-wage workers with little or no experience and rely on the shop-owner's technical knowledge. Since many plasma owners built their expertise through working in small shops and rarely have a formal academic training, they have difficulty reading technical drawings and instead rely on copying samples, leading to less accurate output. Most plasma workshops sell to the retail market or to domestic market suppliers a limited range of simple final products, e.g. pulleys, ship windows. While these retailers may demand a sample product, there is much less emphasis on precision. Generally, retailers emphasize low cost over quality. Moreover, strong competition among retail suppliers inhibits knowledge transfer and encourages production of low-quality, inexpensive products. For knowledge improvement, these plasma workshops depend largely on untargeted, irregularly publicized government programmes, which may not best suit their needs.

Cheap labour and relatively small, erratic job orders reduce the incentive for workshops to specialize or acquire expensive machinery to increase productivity. As one seasoned metalworker explained, the strength of the plasma workshop is the flexibility to do smaller orders. However, this flexibility becomes a liability to capacity development when workshops have to meet many small orders and never develop specialization.

Though less direct, the subcontracting system does provide some market opportunities for smaller workshops to benefit from the virtuous circle affecting inti capacity building. Subcontracting plasma increases the incentive to produce higher quality for a higher price, with technical coaching from inti clients in their own virtuous circle. Inti respondents for auto components, for instance, turn to plasma workshops to produce 10-15 percent of their orders from LEs, usually subcomponents of components or basic parts made more cheaply in small workshops, while still passing the quality control requirements of LEs. Often soft loans are provided to plasma to help them acquire new machines capable of higher quality output. Inti and plasma involved in subcontracting are more likely to use the UPTD Lab, especially to test the quality of materials. They are better able to offset lab usage costs through the higher price paid by LEs for quality parts.

Learning takes place through quality control as inti often build a procedure for troubleshooting mistakes into their subcontracting relationships. Inti workshops engage in coaching plasma on quality control standards and in some cases support former employees already familiar with these standards in starting up plasma. ${ }^{14}$ 


\section{Knowledge Diffusion among Small Workshops}

It was stated above that a cluster of producers can be a powerful means for knowledge diffusion. However, in this Tegal case knowledge transfer between small workshops is often contingent on personal networks and is conditioned by competition. On occasion, among workshops producing for the retail market, competition can sometimes become 'unhealthy' which has an opposite effect, inhibiting knowledge diffusion among them. For example, when a competing firm bought off a shopowner's driver after a marketing trip and followed up with lower bids to the same potential clients. Many workshop owners were worried about firms' tactics to reduce production costs, often at the expense of quality. Some workshops find the right combination of cheap scrap metals to get their products to pass buyers' inspection standards, but these lower-quality items wear out more quickly and this does little to strengthen the reputation of the Tegal metalworking industry as a whole. This cost-cutting in turn creates price pressures, forcing competing workshops to a race for the bottom in terms of quality.

Small workshop respondents mentioned that there was hesitancy among metalworkers to share new and possibly advantageous technical knowledge. Technical knowledge tends to be shared only amongst personal friends whose shops are not in direct competition. The same hesitancy was evident in giving too much training to employees. Exemployees were likely to start up competing businesses, as was the case with one workshop owner interviewed, who lost 40 percent of his retail market share to ex-employees who began producing ship windows out of lower-grade materials.

Marketing information is even more closely guarded. In addition to the tactics mentioned above, sometimes domestic market suppliers will come to the cluster (sentra) and play the workshops off one against the other, using their proximity and lack of specialization to engage them in competitive price-cutting. The owner of KPY, one of the district's most successful metal workshops in both subcontracting and retail production, explained that lack of trust and mutual suspicion among metalworkers was the main constraint to metal works development and was the prime reason for the lack of growth in metalworkers' associations.

\section{The Role of Government}

While the district government has demonstrated a keen awareness of the importance of enhanced knowledge and skills to improve the com- 
petitiveness of local metalworking shops, it has not been very successful at systematically improving the skills of local firms. It has attempted to both facilitate direct training as well as build up supporting institutions that can assist firms, and to lower information costs among firms. These efforts, while significant and well intentioned, have been handicapped by poor targeting, a lack of sufficient funds, an inadequate number of skilled staff dedicated to the effort, and weak feedback mechanisms between government and metalworking shops.

The government is the only source of managerial training for plasma and retail market workshops as well as many inti that receive only limited management training from LEs clients. Since 2001, the majority of government training has focused on technical subjects or technical quality management processes. For some smaller workshops without direct links to LEs, local government-facilitated technical training remains the only source of technical information outside the past experience of the workshop owner. However, according to respondents who participated in government training, these activities were poorly targeted, often incommensurate with their level of skills or the machinery available; while on occasion the training focused on skills they had already mastered.

The district government has currently linked up with outside institutions, including strong partnerships with the Central Government's Indonesian Agency for the Assessment and Application of Technology (BPPT) and with an NGO, Yayasan Dana Bakti Astra (YDBA). Although this strategy has succeeded in bringing new knowledge to the cluster, what is offered in the way of training is often ill-suited to the needs of participants. In 1997, the district government opened the UPT to enhance subcontracting workshops' capacity to produce high-quality, precision goods. The first government-funded UPT opened in 1982, enabling the metalworking cluster to access the machines necessary to meet their orders. The UPT was not able to keep up with technical advances and soon several of the workshops bought more advanced machinery for their own internal requirements.

\section{Concluding Remarks}

This case study demonstrates three crucial facts. First, despite some limitations, MNCs such as PT Komatsu Indonesia are very important as a source of technology transfer to local SMEs. PT Komatsu is able to increase the technology and hence production capability of 
its inti subcontractors, and indirectly, plasma workshops that have subcontracting links with the inti. This is also supported by Blomstróm and Sjöholm's (1999) analysis of statistical data, showing that industries with a large presence of MNCs are able to increase the production capabilities of local companies. However, MIEs in particular are largely excluded from the direct transfer of technology, as MNCs are more likely to subcontract parts of their production to local firms that already enjoy a certain level of technological capability, and these are mostly MEs and to a lower extent, SEs. This supports the general view in the literature that the more absorptive capacity the local firms have, the more benefit the local firms will gain from a transfer of technology.

The second conclusion to be drawn is that although local SMEs' technical capabilities in the cluster are generally low, many of them (mostly SEs and MEs) have innovation capability, in that they demonstrated an ability to advance from making relatively simple products to supplying metal components with higher grades of precision on a consistent basis. At least, this was demonstrated by the PT Komatsu Indonesia's inti suppliers.

Third, though well-intentioned, the government's role has produced poor measurable results due to (i) inappropriate training materials that fail to meet the needs of producers, (ii) budgetary constraints for managing and maintenance of the UPT, and (iii) a lack of qualified trainers. The local government's training and technical assistance can though claim a limited positive impact, in the sense that it provides assistance to firms that would otherwise receive no assistance at all from other bodies such as LEs or university.

So, the findings may suggest that currently, within SMEs, MEs will derive more benefits from the presence of FDI than their smaller counterparts, as they are better able to meet requirements to become subcontractors. To achieve an optimal spillover effect, this depends on cooperation between MEs as the first technology recipients and SEs and MIEs. This is also the role that government should play in supporting technology capacity building in SEs and MIEs. Failing this, the spillover effect will not materialize or the technology transfer will be limited to MEs; hence the presence of FDI will result in an increased technology gap between MEs, on the one hand, and SEs and MIEs, on the other hand. A key lesson from this case study is to understand how SMEs, especially SEs and MIEs, can best obtain and utilize appropriate technology and how government can promote the most effective technology development pathways. 
Tulus Tahi Hamonangan Tambunan is from the Center for Industry and SME Studies, University of Trisakti, Jakarta Indonesia.

\section{NOTES}

1 It is extremely difficult to measure and compare levels of technological capacity of enterprises or industries directly. Therefore, the measurement of total factor productivity (TFP) or partial productivity for one factor is often used as a proxy for measuring this capacity. One means of establishing levels of technological capacity is achieved by comparing levels of labour productivity.

2 See also previous studies on productivity in Indonesia (particularly in manufacturing) from Shepherd et al. (1998), Hill (2001), Ito (2004), Takii (2004, 2005), Timmer (1999), Rice and Abdullah (2000), Berry et al. (2001) and Takii and Ramstetter (2004).

3 See Thee (1990a, 1990b, 1991), Hill (1988), Thee and Pangestu (1994) and Sato (1998).

4 See for example Hobday (1994), Mans (1996) and World Bank (1996).

5 There is a growing literature on spillover effects from the transfer of technology; see for example, Kokko et al. (1998).

6 For example, diffusion can occur through magazines and newspapers, education programmes and documentaries on television, seminars, workshops, training, plant visits and exhibitions. It can also occur if an Indonesian manager or senior technician employed in a foreign firm leaves this firm to work in a domestic firm. The knowledge or experience received while working for the foreign firm is then deployed in the new job within the local context.

7 See for example Harianto (1993), Kitabata (1988), Sato (2000), Supratikno (2001) and JICA (2000).

8 SAs can take many forms, including subcontracting, joint ventures and cooperation in marketing, promotion or R\&D activities.

9 See for example Sandee (1995) and Sandee and ter Wingel (2002).

10 The scale of each assistance programme varied greatly, based on the amount of funds, time frame and geographical scope.

11 For discussion explicitly or implicitly on the government programmes to support SMEs in Indonesia, see for instance Klapwijk (1997), Sandee (1994, 1995), Sandee et al. $(1994,2000,2002)$, van Dierman $(1997,2004)$ and Sato $(2000)$.

12 In this scheme, introduced on a nationwide basis in February 1992, all state-owned enterprises and big private companies (LEs) are required to assist SMEs with capital, training and technical assistance, marketing, procurement of raw materials, inter alia. For example, with respect to marketing, the parent companies provide promotion facilities such as trade exhibitions and study tours for the supported enterprises or act as a trading house. With respect to technology, the parent companies give financial assistance for the purchase of new machines or provide them with technical training or technicians during the innovation process.

13 These two industries were selected by the local government for intensive assistance based on existing competency. According to Mr. Dasuki, Head of the Industrial Affairs Sub-Agency, the industries showing the greatest competency are those seen as having access to key markets, those with many (including small) workshops involved in production, and having developed quality management systems. 
14 A plasma subcontractor for KPY, one of PT Komatsu's inti, explained that his company received useful technical coaching as part of a quality control process conducted upon delivery of his product to KPY.20 In a case of knowledge spillover, his firm applied some of these technical lessons not only to his subcontracting operations, but also to the production of retail market goods.

\section{REFERENCES}

Agrawal, Ajay 2001. 'University-to-Industry Knowledge Transfer: Literature Review and Unanswered Questions.' International Journal of Management Review 3(4): 370 85.

Anselin, L, A. Varga and Z. Acs 1997. 'Local Spillovers between University Research and High Technology Innovations.' Journal of Urban Economics 42(3): 210-26.

Bappeda 2005, Pembangunan Ekonomi di Kabupaten Tegal 2005, Kabupaten Tegal: Badan Perencanaan Pembangunan Daerah.

Berry, Albert and Brian Levy 1994. 'Indonesia's Small and Medium-Size Exporters and Their Support Systems.' Policy Research Working Paper No. 1402, December. Policy Research Department, Finance and Private Sector Development Division. Washington, DC: World Bank.

Berry, Albert, Edgard Rodriguez and Henry Sandee 2001. 'Small and Medium Enterprise Dynamics in Indonesia.' Bulletin of Indonesian Economic Studies 37(3): 363-84.

Blomström, M and F. Sjöholm 1999, 'Technology Transfer dan Spillovers: Does Local Participation with Multinationals Matter?', European Economic Review 43: 915-23.

BPS 2005, Kabupaten Tegal Dalam Angka 2005, Kabupaten Tegal: Biro Pusat Statistik.

Cole, William 1998. 'Bali's Garment Export Industry.' In Hal Hill and Thee Kian Wie (eds), Indonesia's Technological Challenge. Research School of Pacific and Asian Studies, Australian National University, Canberra, and Institute of Southeast Asian Studies, Singapore: 255-78.

Doeringer, Peter B. and David G. Terkla 1995. 'Business Strategy and Cross-Industry Clusters.' Economic Development Quarterly 9(3): 225-37.

Harianto, Farid 1993. 'Study on Subcontracting in Indonesian Domestic Firms.' Jakarta: PEP-LIPI.

Hill, Hal 1988. Foreign Investment and Industrialization in Indonesia. Singapore: Oxford University Press.

- 2001. 'Small and Medium Enterprises in Indonesia: Old Policy Challenges for a New Administration.', Asian Survey 41(2): 248-70.

Hobday, Michael 1994. 'Export-led Technology Development in the Four Dragons; The Case of Electronics.' Development and Change 25(2): 393-61.

Humphrey, John and Hubert Schmitz 1995. 'Principle for Promoting Clusters and Network of SMEs.' Paper commissioned by Small and Medium Enterprise Branch, Institute of Development Studies, University of Sussex, Brighton.

Ito, Keiko 2004. 'Foreign Ownership and Productivity in the Indonesian Automobile Industry: Evidence from Establishment Data for 1990-1999.' In Takatoshi Ito and Andrew Rose (eds), Growth and Productivity in East Asia. National Bureau of Economic Research, East Asia Seminar on Economics, Vol. 13. Chicago: University of Chicago Press: 44-65.

Jacob, Jojo and Christoph Meister 2005. 'Productivity Gains, Technology Spillovers and Trade: Indonesian Manufacturing, 1980-96.' Bulletin of Indonesian Economic Studies 41(1): 37-56.

JICA 2000. 'Study on Inter-firm Linkages and Financial Needs for the Development of 
Small and Medium Scale Manufacturing Industry in Indonesia.' Jakarta: Japan International Cooperation Agency in cooperation with PT Kami Karya Nusantara.

Kitabata, T. 1988. Report on the Subcontracting System in the Indonesian Machinery Industries. Tokyo: Japan International Cooperation Agency (JICA).

Klapwijk, Martin 1997. 'Rural Industry Clusters in Central Java, Indonesia. An Empirical Assessment of their Role in Rural Industrialization.' Unpublished PhD dissertation, Tinbergen Institute Research Series No. 153. Free University Amsterdam.

Kokko, A., R. Tansini and M. C. Zejan 1998. 'Local Technological Capability and Productivity Spillovers from FDI in the Uruguayan Manufacturing Sector.' Journal of Development Studies 32(4): 602-11.

Lall, Sanjaya and Kishore Rao 1995. 'Indonesia: Sustaining Manufactured Export Growth', Vol. 1. Revised draft report submitted to the National Planning Board (Bappenas), Jakarta, August.

Mans, Darius 1996. 'Indonesia: Industrial Technology Development for a Competitive Edge.' Indonesia Discussion Paper Series 4. Jakarta: World Bank.

Nadvi, K. and H. Schmitz 1994. 'Industrial Clusters in Less Developed Countries: Review of 15 Experiences and Research Agenda.' IDS Discussion Paper No. 339, Institute of Development Studies. Brighton: Sussex University.

Perry, C. and R. Pyatt 1995. The Space of Network Relationships in a Southeast Asian Setting. Melbourne: Academy of Marketing Science.

Rice, R. and I. Abdullah 2000. 'A Comparison of Small and Medium/Large Indonesian Manufacturing Enterprises from 1986 and 1996 by Sector.' Mimeo, Jakarta: Partnership for Economic Growth Project, USAID.

Sandee, Henry 1994. 'The Impact of Technological Change on Interfirm Linkages. A Case Study of Clustered Rural Small-Scale Roof Tile Enterprises in Central Java.' In P. O. Pedersen, A. Sverrisson and M. P. van Dijk (eds), Flexible Specialization. The Dynamics of Small-Scale Industries in the South. London: Intermediate Technology Publications: 72-95.

- 1995. 'Innovation Adoption in Rural Industry: Technological Change in Roof Tile Clusters in Central Java, Indonesia.' Unpublished PhD dissertation, Vrije Universiteit, Amsterdam.

- 1996. 'Small-Scale and Cottage Industry Clusters in Central Java: Characteristics, Research Issues, and Policy Options.' Paper presented at the International Seminar on Small Scale and Micro Enterprises in Economic Development Anticipating Globalization and Free Trade, Satya Wacana Christian University, November 4-5, Salatiga.

Sandee, Henry and J. ter Wingel 2002. 'SME Cluster Development Strategies in Indonesia: What Can We Learn from Successful Clusters?' Paper presented at JICA Workshop on Strengthening Capacity of SME Clusters in Indonesia, March 5-6, Jakarta.

Sandee, Henry, P. Rietveld, Hendrawan Supratikno and P. Yuwono 1994. 'Promoting Small Scale and Cottage Industries. An Impact Analysis for Central Java.' Bulletin of Indonesian Economic Studies 30(3): 115-42.

Sandee, Henry, Roos Kities Andadari and Sri Sulandjari 2000. 'Small Firm Development during Good Times and Bad: The Jepara Furniture Industry.' In C. Manning and P. van Dierman (eds), Indonesia in Transition: Social Aspects of Reformasi and Crisis. Indonesia Assessment Series, Research School of Pacific and Asian Studies, Australian National University, Canberra, and Institute of Southeast Asian Studies, Singapore: 184-98.

Sandee, Henry, B. Isdijoso and Sri Sulandjari 2002. SME Clusters in Indonesia: An Analysis of Growth Dynamics and Employment Conditions. Jakarta: International Labor Office (ILO).

Sato, Yuri 1998. 'The Transfer of Japanese Management Technology to Indonesia.' In H. Hill and Thee Kian Wie (eds), Indonesia's Technological Challenge. Research School of 
Pacific and Asian Studies, Australian National University and Institute of Southeast Asian Studies: 326-41.

- 2000. 'Linkage Formation by Small Firms: The Case of a Rural Cluster in Indonesia.', Bulletin of Indonesian Economic Studies 36(1): 137-66.

Schiller, J. and B. Martin-Schiller 1997. 'Market, Culture and State in the Emergence of an Indonesian Export Furniture Industry.' Journal of Asian Business 13(1): 1-23.

Shepherd, W. F., A. Szirmai and D. S. Prasada Rao 1998. 'Indonesia Manufacturing Sector Output and Productivity: An Australian Comparative Perspective, 1975-90.' Bulletin of Indonesian Economic Studies 34(2): 121-42.

Sjöholm, Fredrik 1999a. 'Exports, Imports and Productivity: Results from Indonesian Establishment Data.' World Development 27(4): 705-15.

- 1999b. 'Productivity Growth in Indonesia: The Role of Regional Characteristics and Direct Foreign Investment.' Economic Development and Cultural Change 47(3): 559-84.

SMERU 2004. 'Mapping Assistance Programs to Strengthen Microbusinesses.' Smeru News No. 10, April-June.

SRI International 1992. 'Technology Development Plan for Indonesia's Engineering Industries.' Draft final report for the Ministry of Industry, Republic of Indonesia, Jakarta.

Supratikno, Hendrawan 2001. 'Subcontracting Relationship in Indonesian Manufacturing Firms.' Gadjah Mada International Journal of Business 3(2): 115-27.

- 2002. 'The Strategies of Cluster Upgrading in Central Java.' A Preliminary Report to Depperindag, Salatiga.

TAF 2000. 'Strategic Alliances and Development of Small and Medium-Scale Enterprises in Indonesia.' Final Report, May, The Asia Foundation, Jakarta.

Takii, Sadayuki 2004. 'Productivity Differentials between Local and Foreign Plants in Indonesian Manufacturing, 1995.' World Development 32(11): 1957-69.

- 2005. 'Productivity Spillovers and Characteristics of Foreign Multinational Plants in Indonesian Manufacturing 1990-1995.' Journal of Development Economics 76(2): $521-42$.

Takii, Sadayuki and Eric D. Ramstetter 2004. 'Employment, Production, Labour Productivity, and Foreign Multinationals in Indonesian Manufacturing, 1975-2000.' Working Paper No. 25, International Centre for the Study of East Asian Development, Kitakyushu.

Takii, Sadayuki and Eric D. Ramstetter 2005. 'Multinational Presence and Labour Productivity Differentials in Indonesian Manufacturing, 1975-2001.' Bulletin of Indonesian Economic Studies 41(2): 221-42.

Tambunan, Tulus T. H. 1998. 'Cluster Diagnosis in Padang Rattan Industries and Proposed Action Plan.' Study report, October, UNIDO, Jakarta.

- 2000. Development of Small-Scale Industries during the New Order Government in Indonesia, Aldershot: Ashgate.

- 2006. Development of Small and Medium Enterprises in Indonesia from the Asia-Pacific Perspective. Jakarta: LPFE-Usakti.

Thee Kian Wie 1990a. 'Indonesia: Technology Transfer in the Manufacturing Industry.' In Hadi Soesastro and Mari Pangestu (eds), Technological Challenge in the Asia Pacific Economy. Sydney: Allen \& Unwin: 23-43.

- 1990b. 'Prospects for Cooperation in Technology.', In Kim Seung Jin and Suh Jang Won (eds), Cooperation in Small and Medium-Scale Industries in ASEAN. Kuala Lumpur: Asian and Pacific Development Centre: 40-55.

- 1991. 'The Surge of Asian NIC Investment to Indonesia.' Bulletin of Indonesian Economic Studies 27(3): 55-88. 
Tulus Tahi Hamonangan Tambunan

- 1994. 'Technology Transfer from Japan to Indonesia.' In Yamada Keiji (ed.), The Transfer of Science and Technology between Europe and Asia, 1780-1880. Kyoto: International Research Center for Japanese Studies: 30-59.

- 1997. 'The Development of the Motor Cycle Industry in Indonesia.' In Mari E. Pangestu and Yuri Sato (eds), Waves of Change in Indonesia's Manufacturing Industry. Tokyo: Institute of Developing Economies (IDE): 93-111.

- 1998. 'Determinants of Indonesia's Industrial Technology Development.' In H. Hill and Thee Kian Wie (eds), Indonesia's Technological Challenge. Singapore: Research School of Pacific and Asian Studies: 117-35.

- 2003. 'The Major Channels of International Technology Transfer to Indonesia: An Assessment.' Paper presented at the Conference on Catch-Up Growth and Technology Transfer, Groningen Center for Growth and Development, University of Groningen, 17-18 October.

- 2005. 'The Major Channels of International Technology Transfer to Indonesia: An Assessment.' Journal of the Asia-Pacific Economy 10(2): 214-36.

Thee Kian Wie and Mari Pangestu 1994. 'Technological Capabilities and Indonesia's Manufactured Exports.' Revised report for UNCTAD/SAREC Project on Technological Dynamism and the Export of Manufactures from Developing Countries, January.

Timmer, Marcel P. 1999. 'Indonesia's Ascent on the Technology Ladder: Capital Stock and Total Factor Productivity in Indonesia Manufacturing, 1975-95.' Bulletin of Indonesian Economic Studies 35(1): 75-97.

Van Dierman, Peter 1997. Small Business in Indonesia. Aldershot: Ashgate.

- 2004. 'The Economic Policy Environment for Small Rural Enterprises in Indonesia.' In Thomas R. Leinbach (ed.), The Indonesian Rural Economy Mobility, Work and Enterprise. Singapore: ISEAS: 95-117.

Weaver, K. Mark and Pat H. Dickson 1995. 'Towards a Unified Model of SME-based Strategic Alliances: Transaction Costs, Resource Dependencies and Social Controls.' Paper submitted to the Academy of Management Entrepreneurship Division, Department of Management and Marketing, The University of Alabama.

WEF 2005. The Global Competitiveness Report 2005-2006. Geneva: World Economic Forum.

Weijland, H. 1992. 'The Role of Middlemen in Rural Industry. An Empirical Study of Rural Industry in 25 Indonesian Provinces.' Mimeo, Faculty of Economics, Free University Amsterdam.

World Bank 1996. 'Indonesia - Industrial Technology Development for a Competitive Edge.' Report No. 15451-IND, May. Washington, DC: World Bank.

- 2006. 'Revitalizing the Rural Economy: An Assessment of the Investment Climate Faced by Non-farm Enterprises at the District Level.' Consultative Draft Report, July, Jakarta. 